\title{
The Effect of Discovery Learning Model with Scaffolding on Students' Cognitive Learning Outcome at Tourism Area in The Special Region of Yogyakarta
}

\author{
${ }^{1 s t}$ Zendi Dermawan \\ Science Education, Postgraduate \\ Program, Faculty of Teacher \\ Training and Education \\ Universitas Sebelas Maret \\ Indonesia \\ zendidermawan@gmail.com
}

\author{
2nd Widha Sunarno \\ Physics Education, Faculty of \\ Teacher Training and Education, \\ Universitas Sebelas Maret \\ Indonesia \\ widhasunarno@staff.uns.ac.id
}

\author{
${ }^{3 r d}$ Suciati Suciati \\ Science Education, Postgraduate \\ Program, Faculty of Teacher \\ Training and Education \\ Universitas Sebelas Maret \\ Indonesia \\ suciatisudarisman@staff.uns.ac.id
}

\begin{abstract}
This research is aimed at figuring out the effect of discovery learning model with scaffolding on students' cognitive learning outcome of the eleventh science class (XI MIPA) at tourism area in the Special Region of Yogyakarta. This research is an experimental research. The research was designed by employing Pretest-Posttest Control Group Design. The sampling technique used by the researchers was the cluster random sampling of 224 students of XI MIPA in some state senior high schools (SMA Negeri) at tourism area in Special Region of Yogyakarta. The data collection techniques were test and non-test. The test was pretest and posttest used to measure students' cognitive learning outcome and the non-test was observation, documentation, and interviews. The data, moreover, were analyzed using prerequisite tests such as normality test of Kolmogorov-Smirnov, homogeneity test of Levene and t-test independent sample to test the hypothesis analysis. The result showed that there is a significant effect of learning discovery learning model with scaffolding on students' cognitive learning outcome. The significant value of $0,005<0,05$ and Tscore > Ttable $(2,889>1,65168)$ means $\mathrm{HO}$ is rejected and $\mathrm{H} 1$ accepted. The conclusion drawn from the research is that there is the positive and significant effect of implementing discovery learning model with scaffolding on students' cognitive learning outcome.
\end{abstract}

Keywords-discovery learning model with scaffolding, cognitive learning outcome, tourism area

\section{INTRODUCTION}

The development of globalization era is identical with the rapid development of science and technology. The development of science and technology demands a good education world to be able to produce human resources that can compete in the current globalization. Ngang, et al. (2013) [32] states that in the future the education system is prepared to build a competitive generation with the ability to think and to solve all problems and global issues. The provision can be obtained by students at schools through biology learning that is in accordance with its nature as a science.

Biology is a part of science in which science learning, as one of the advancement driving forces in the era of globalization, put forward four science domains: product, process, attitude and technology [6]. Biology as a product refers that products in biology learning like the principle, law, fact, and theories have been accepted. Biology as a process means that learning biology is a way to gain knowledge through the scientific method. Biology as an attitude refers that in biology learning, the learners are able to develop the scientific attitude such as discipline, objective and meticulous. Biology as a technology means that the concept of science could be applied in everyday life in various technology products [9].

Biology learning which promotes products, processes, attitudes, and technology is in line with the 2013 curriculum. The 2013 curriculum is developed to cope with the development of globalization by applying competency standard that includes attitudes, knowledge, and skills [20]. Learning in the 2013 curriculum emphasizes on the scientific approach. The scientific approach is a learning process designed to enable students to construct concept, law or principle. It covers five aspects: (1) observing; (2) questioning; (3) collecting information lexperimenting; (4) associating/processing the obtained information and (5) communicating [19].

Biology learning that emphasizes the scientific approach or inquiry will facilitate students in scientific activities so that students' scientific thinking ability will be trained [8]. High scientific thinking ability will give the positive impact on students' cognitive learning outcome [34]. Inquiry-based learning will facilitate students to be active in scientific activities in order to have an impact on improving student learning outcome [2]. 
Based on the observation result, it was found that a passive learning process is seen when teachers dominate in the learning process in the classroom (teacher-centered learning) and student are required to memorize the material. Seen from the condition of the students in the learning process, it was found that students are less active and feel difficult in understanding, connecting and analyzing concept with the problem. Based on the result of the interview with teachers, it was known that teachers find it difficult to direct students in conducting active learning that facilitates students to seek knowledge independently.

There are several factors that can affect student learning outcome such as learning method and student learning environment [33]. Learning environment factors include parental attitudes that play a role in monitoring and improving physical, emotional and intellectual characteristics to improve student learning outcome [17].

The Special Region of Yogyakarta is famous for its tourism area. The tourism areas greatly contribute to the economy, increase foreign exchange, create jobs, improve the living standard and contribute to the development of regional imagery [17]. Increasing the economy of people at tourism areas has an impact on education improvement [22]. An economic condition, employment status, and parents' educational rates have a positive relationship to student learning outcomes [1].

Based on observation result, in fact, at one of the tourism areas in the Special Region of Yogyakarta shows the average of cognitive learning outcome of students in the last three semesters is 68,70 and 65 meanwhile the minimum competency score is 78 , so it can be concluded that students' cognitive learning outcomes are still not yet optimal.

Based on the problem there is a gap between expectation and reality. The success in optimizing student learning outcomes is affected by several factors, one of which is the application of learning model [5]. Therefore, it is necessary to apply learning model that can motivate students in learning and suit with the effectiveness of all students, one of them is the inquiry-based learning model [35]. The inquirybased learning model requires students to solve problems through investigation activities, thereby it will increase their knowledge independently which impact on improving learning outcomes [14]. Learning activities in the inquiry-based learning consist of scientific questions, formulating hypotheses, designing experiments, collecting data, analyzing data and drawing conclusions [16]. Implementation of the inquiry-based learning model has the potential to optimize student learning outcomes by positioning students as active learners through investigation activities.
One of the inquiry-based learning models that has potential to optimize student learning outcomes is the discovery learning model. The Discovery learning model is one of the recommended learning models in the 2013 curriculum. The application of discovery learning model requires students to be active in exploring and solving problems, generalizing knowledge and confirming previous knowledge toward new knowledge [12]. Discovery learning model consists of five phases: (1) orientation; (2) hypothesis generation; (3) hypothesis testing; (4) conclusion; and (5) regulation [18]. Based on the stages, discovery learning model has emphasized on product, process, attitude and scientific approach. The discovery learning model has advantages in facilitating students to solve problems and improve students' cognitive abilities [33]. The discovery learning model also has some disadvantages that in its execution it takes a lot of time and students less ready to make the discovery of complex knowledge [15]. Therefore, inserting scaffolding into the syntax of discovery learning is needed to anticipate shortcoming as scaffolding helps the development of new skill and concept in learning so that students 'learning independence also increases which soon affects students' learning outcomes [24]. Scaffolding is given gradually at the beginning of the learning so that students can construct knowledge and when the competence of students' knowledge increases then scaffolding will be reduced until finally eliminated [33]. Scaffolding consists of three phases: (1) environmental provisions; (2) explaning, reviwing, and restructuring; and (3) developing conceptual thinking [13].

Discovery learning model with scaffolding is a new alternative in biology learning. The model facilitates students in conducting investigation activities such as identifying phenomenon, formulating problems, making hypothesizing, searching and processing information to communicate the concept. The application of discovery learning model with scaffolding is expected to optimize students' cognitive learning outcome.

Based on the background of the problem, the researchers conducted a research entitled The Effect of Discovery Learning Model with Scaffolding on Students' Cognitive Learning Outcome at Tourism Area in The Special Region of Yogyakarta.

\section{RESEARCH METHODOLOGY}

This study was conducted in some schools located at the tourism area in the Special Region of Yogyakarta which consists of 4 states senior high schools. The population of this study is all students of XI MIPA in some state senior high schools (hereafter SMA) at the tourism area in the Special Region of Yogyakarta in the academic year of 2017/2018. The sample of this study amounted to 224 students of class XI MIPA in SMAN 1 Prambanan, SMAN 1 
Kalasan, SMAN 8 Yogyakarta and SMAN 1 Imogiri. The sampling technique uses cluster random sampling. Cluster random sampling has taken on sampling within the cluster so that each object is considered to have equal opportunity to be taken as a sample [31].

This research is an experimental research which is used to see the symptoms that appear in a certain condition if treatment is given [31]. The research design uses the pretest-posttest control group design. In this study, two groups were involved in experimental group using discovery learning model with scaffolding and control group using expository model. The research design of pretest-posttest control group design is presented in TABLE 1.

TABLE 1. PRETEST POSTTEST CONTROL GROUP DESIGN

\begin{tabular}{lccc}
\hline Group & Pretest & Treatment & Postest \\
\hline Experiment & $\mathrm{T} 1$ & $\mathrm{X} 1$ & $\mathrm{~T} 2$ \\
\hline Control & $\mathrm{T} 1$ & $\mathrm{X} 2$ & $\mathrm{~T} 2$ \\
\hline
\end{tabular}

Explanation:

$\mathrm{X} 1$ : Learning process using discovery learning model with scaffolding.

$\mathrm{X} 2$ : The learning process uses an expository model.

T1: Pretest is given to the experimental and control group prior to treatment.

T2: Posttest is given to the experimental and control groups after treatment.

To see the effect of the discovery learning model with scaffolding on the experimental group and the expository model on the control group, the pretest was given, followed by treatment and the posttest was given to know the learning outcomes of each group. For normality test, the researchers uses Kolmogorov Smirnov test. In addition, homogeneity test, the researchers use Levene 's test and for the hypothesis test, the researchers use the t-test.

\section{RESULT}

\section{A. Description of Pretest Data (Before Giving Treatment)}

Pretest data is the data of students' cognitive learning outcome before being given different treatment at each research group. The following description of pretest data from experimental and control groups is presented in TABLE 2.

\section{TABLE 2. PRETEST DATA DESCRIPTION}

\begin{tabular}{ccccc}
\hline Group & Max. & Min. & Mean & Std. Dev. \\
\hline Experiment & 85 & 40 & 60,71 & 11,871 \\
\hline Control & 85 & 40 & 61,87 & 11,876 \\
\hline
\end{tabular}

Based on the data presented in TABLE 2. the average pretest score in the experimental group is 60,71 and the mean score in the control group is 61,87 . This means that the average pretest score of the control group is higher than the average score of the experimental group. The maximum pretest score of the experimental and control groups have in common that is 85 . The minimum pretest values of the experimental and control groups have similarity that is 40 . The standard deviation of the experimental group is 11,871 and the control group is 11,876 .

\section{B. Description of Posttest Data (After Treatment)}

Posttest data is data of the students' cognitive learning outcome after given different treatment to each research group. The following description of posttest data from the experimental and control groups is presented in TABLE 3 .

\section{TABLE 3. POSTTEST DATA DESCRIPTION}

\begin{tabular}{ccccc}
\hline Group & Max. & Min. & Mean & Std. Dev. \\
\hline Experiment & 100 & 60 & 81,61 & 9,353 \\
\hline Control & 95 & 55 & 75,98 & 11,086 \\
\hline
\end{tabular}

Based on the data in TABLE 3. the average posttest score in the experimental group is 81,61 and the mean score in the control group is 75,98. This means that the average score of the experimental group posttest is higher than the mean of the control group. Meanwhile, the maximum posttest score of the experimental group is 100 and for the control group is 60. In addition, the minimum posttest of the experimental group is 60 and for the control group is 55. The standard deviation of the experimental group is 9,353 and control group is 11,086.

The following comparison of the average pretest score and posttest score is presented in Fig. 1. and Fig. 2.

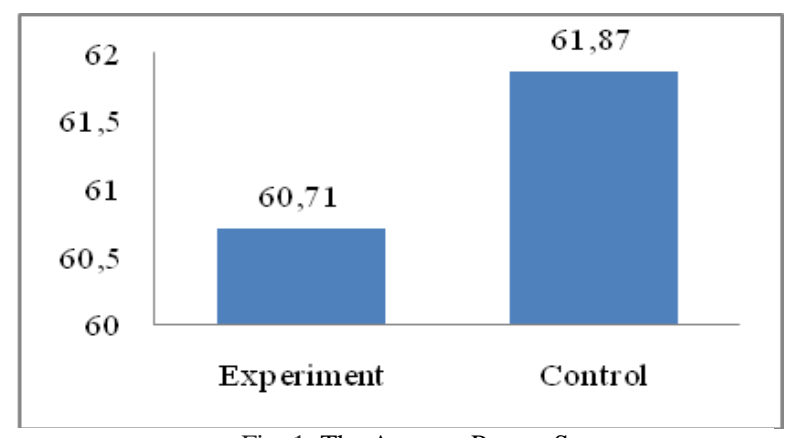

Fig. 1. The Average Pretest Score

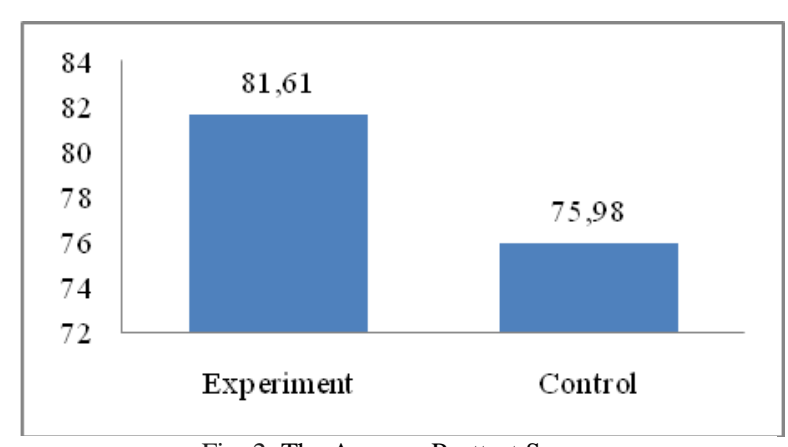

Fig. 2. The Average Posttest Score 
Based on the data in Fig. 1. the average pretest score in the experimental group is 60,71 and the mean score in the control group is 61,87 . This means that the average pretest score of the control group is higher than the average score of the experimental group. In the Fig. 2. the average posttest score in the experimental group is 81,61 and the mean score in the control group is 75,98 . This means that the average score of the experimental group posttest is higher than the mean of the control group.

\section{Test Prerequisites}

Hypothesis testing was conducted after the prerequisite test to determine that the hypothesis test statistics to be used. The prerequisite test used is the normality test and homogeneity test.

\section{A. Normality Test}

Normality test is conducted to know a sample come from the population has normal distribution or not. Normality test used was Kolmogorov Smirnov test with $\alpha=0,05$. Criteria of judicial decision is if the value of significance is greater than $\alpha(\mathrm{Sig} .>\alpha)$, then it can be said that the distribution is normal. The following test result shows the normality of pretest and posttest data of cognitive learning outcomes. It is presented in TABLE 4.

TABLE 4. NORMALITY TEST RESULT OF PRETEST AND POSTTEST

\begin{tabular}{lccc}
\hline Data & \multicolumn{2}{c}{ Sig Value. of Each Group } & Decision \\
\cline { 2 - 3 } & Experiment & Control & \\
\hline pretest & 0,105 & 0,069 & $\begin{array}{c}\text { Sig. }>\alpha \\
\text { normal }\end{array}$ \\
\hline posttets & 0,200 & 0,188 & $\begin{array}{l}\text { Sig. }>\alpha \\
\text { normal }\end{array}$ \\
\hline
\end{tabular}

Based on TABLE 4, it shows that the results normality test of pretest and posttest in the experimental group are 0,105 and 0,200, respectively, while the normality test of pretest and posttest in the control group are 0,069 and 0.188 , respectively. This means that the normality test result for each pretest and posttest data in the experimental and control groups is greater than $\alpha=0,05$. This shows that the normality test of pretest and posttest for each group is normally distributed.

\section{B. Homogeneity Test}

Homogeneity test is performed to find out whether the data is homogeneous or not. Homogeneity test used is in this research Levene test with $\alpha=0,05$. Criteria for the decision of the test is if the value of significance is greater than $\alpha=0,05$ (Sig. $>\alpha$ ), then it can be said that the distribution is the homogeneous data. The following result shows the homogeneity of pretest and posttest of cognitive learning outcomes. It is shown in TABLE 5.
TABLE 5. HOMOGENEITY TEST RESULT OF PRETEST AND POSTTEST

\begin{tabular}{llll} 
Data & Grup & Sig. Value & Decision \\
\hline Pretest & $\begin{array}{l}\text { Experiment } \\
\text { and Control }\end{array}$ & 0,093 & $\begin{array}{l}\text { Sig.Value }>\alpha \\
\text { Homogenous }\end{array}$ \\
\hline Posttets & $\begin{array}{l}\text { Experiment } \\
\text { and Control }\end{array}$ & 0,074 & $\begin{array}{l}\text { Sig.Value }>\alpha \\
\text { Homogenous }\end{array}$ \\
\hline & Based on TABLE 5. It
\end{tabular}

Based on TABLE 5. It shows that the homogeneity test of pretest result in the experimental group is 0,093 , while the homogeneity test of posttest in the control group is 0,074 . This means that the homogeneity test result on each pretest and posttest data in both experimental and control group are greater than $\alpha=0,05$. This shows that the value variant in the experiment and control classes is the same.

\section{Hypothesis Testing}

After the prerequisite test is met, then the hypothesis testing is done. The data, then was analyzed using is t-test. The criteria used in hypothetical decision making is the level of significance $(\alpha): 0,05$, that $\mathrm{H}_{0}$ is rejected if the probability significance $(\mathrm{sig})<\alpha(0,05)$. This means that if the probability significance ( $\mathrm{sig})<0,05$ then the null hypothesis $\left(\mathrm{H}_{0}\right)$ is rejected and if the probability significance (sig) $>0,05$ then the null hypothesis is accepted. Testing hypothesis of the null hypothesis $\left(\mathrm{H}_{0}\right)$ and the alternative hypothesis $\left(\mathrm{H}_{\mathrm{A}}\right)$ is as follows:

$\mathrm{H}_{0}$ : Discovery learning model with scaffolding does not affect students' cognitive learning outcome.

$\mathrm{H}_{\mathrm{A}}$ : Discovery learning model with scaffolding has the effect on students' cognitive learning outcome.

The hypothesis test result is presented in TABLE 6.

TABLE 6. HYPOTHESIS TEST RESULT USING THE T-TEST

\begin{tabular}{ccccc}
\hline $\begin{array}{c}\text { Learning } \\
\text { Outcome }\end{array}$ & T & Df. & Sig. & Decision \\
\hline Posttest & 2,889 & 110 & 0,005 & $\begin{array}{c}\mathrm{H}_{0} \text { is } \\
\text { rejected, } \\
\text { (there is the } \\
\text { effect) }\end{array}$ \\
\hline
\end{tabular}

Based on TABLE 6, it appears that the significant value of cognitive learning outcome of the posttest is 0,005 . This shows that $\mathrm{H}_{0}$ is smaller than $\alpha$ $(0,05)$ and Tscore $>$ Ttable $(2,889>1,65168)$ that $\mathrm{H}_{0}$ is rejected, it means that there is the difference (effect). This means that there is effect on cognitive learning outcome of posttest, thus the discovery learning model with scaffolding affects students' cognitive learning outcome.

\section{DISCUSSION}

The researcher used the following two treatments in the present study:

a. Taught by using discovery learning model with scaffolding (experimental group). 
b. Taught by using ekspository model (control group).

Student in the experimental group were instructed with discovery learning model with scaffolding. In the instruction based on discovery learning model with scaffolding, teaching and learning activities and lesson plans were designed to maximize students active involvement in the learning process. Here is the phase of the discovery learning model with scaffolding: (1) environmental provisions; (2) orientation; (3) explaning, reviewing, and restructuring; (4) hypothesis generation; (5) hypothesis testing; (6) conclusion; (7) developing conceptual thinking and (8) regulation [18];[13]

In the environmental provisions phase, teachers map out the students' initial knowledge through the test of learning outcomes, while the students perform mapping tests. In the orientation phase, students identify the problem phenomena and formulate problems, while teachers facilitate them. In the explaining, reviewing, and restructuring phase, Teachers help students to constuct new knowledge start from formulating problems to finding the concepts, while students identify problems to find a concept. In the hypothesis generation phase, students formulate a hypothesis based on the formulation of the problem, while teachers facilitate them. In the hypothesis testing phase, students do experiments to prove the hypothesis, while teachers facilitate them. In the conclusion phase, students make conclusions based on experiments, while teachers facilitate them. In the developing conceptual thinking phase, teachers help students to discuss the final answer and looking for alternative answers, while the students discuss the final answer and look for alternative answers. In the regulation phase, students confirm and evaluate learning outcomes, while teachers facilitate them.

In the control group, a teacher directed strategy representing the ekspository model was used. The teacher used direct teaching and question and answer methods to teach related topics . Basic explanations. teaching approach where students are completely passive, were used while teaching the hidden strangles unit. Teaching strategies consisted of the teacher's explanations and textbooks. In this group, the teacher provided instruction through lecture and discussion methods to teach the concepts. The teacher structured the entire class as a unit, wrote notes on the chalkboard about the definition of concepts, and passed out worksheets for students to complete. The primary underlying principle was that knowledge takes the form of information that is transmitted to students. After the teacher's explanations, some concepts were discussed, prompted by teacherdirected questions.

The result of this study indicates that the discovery learning model with scaffolding applied to the experimental group had the effect on the students' learning outcome compared to the exposure model in the control class. The average pretest value of control group is higher than the experimental group that is 61,87 and 60,71 . The average posttest of experiment group is higher that is 81,61 compared to control group that is 75,98 . The experimental group posttest score is higher because the use of discovery learning model with scaffolding causes the students to be more active to think and look for how to solve the given problems.

Based on hypothesis test $\left(\mathrm{H}_{0}\right)$, t-test of discovery learning model along with scaffolding has the effect on students' cognitive learning outcome with the significance value of 0,005 . The value of significance is smaller than the value $\alpha=0.05$, this shows that the model discovery learning with scaffolding affects the students' cognitive learning outcome. The results of this study are in accordance with the results of research Suendarti (2017) [21] that the discovery learning model is very good to implement in science learning because the discovery learning model basically requires students in exploring and developing students' knowledge so that the impact can improve learning outcome. In line with this, Jew (2012) [28] says that the discovery learning model can improve the mastery of material, retention, transfer of knowledge and more significant learning. The Increasing knowledge of students will affect the result of learning / academic achievement and mastery of concept in learning [29]. Rahmann \& Maarif (2014) [27] stated that learning outcome using discovery learning model is better tahn learning outcome using expository model. The same things Melani, et al. (2012) [26] explains that there is a significant influence in the application of discovery learning model to student learning outcome.

Inserting scaffolding on discovery learning syntax is needed to anticipate the shortcomings of the discovery learning model. Scaffolding has a positive impact on students in developing new skills and concepts in learning [3]. As the development of new skills and concepts in learning, students 'independence also increases, which affects students' learning outcomes [15].

Learning outcome can be affected by several factors one of which is the environment [11]. The tourism area contributes greatly to the economy and improves the living standard of the surrounding community [7]. indirectly the role of economics in tourism area has a positive effect on student learning outcomes because the role of economic impacts on the completeness of facilities and the instructional learning that allows students to obtain information required students [23]. The tourist area has the environmental condition withe the high level of education indirectly will have an impact on the high ability of students' scientific thinking [17]. The ability of optimal scientific thinking enables improving student learning outcomes [4]. Kahn, et al. (2015) [25] state that highly educated parents have a greater 
influence on children to study and achieve well in their education at secondary school, same as (Slameto, 2010) [30] which states that student learning outcome can also be influenced by internal factors and external factors. Internal factors such as physical factors, psychological factors, and factor factors, while those included in external factors are the family factor, and school factor.

\section{CONCLUSION}

Based on the result of hypothesis testing, it can be concluded that there is a positive and significant effect of the implementation of discovery learning model with Scaffolding on XI MIPA students' cognitive learning outcomes at tourism areas in the Special Region of Yogyakarta. This is supported by the result of t-test with 5\% significance level which indicates that the value of significance is smaller than $\alpha=0,05(0,005<0,05)$ and Tscore $>$ Ttable $(2,889>$ $1,65168)$ so the reject the null hypothesis and accept alternative hypothesis.

Despite the student learning outcome can be affected by the learning method, the environmental factors in tourism area such as economic factors, education level, and school environment indirectly can also affect it.

\section{ACKNOWLEDGMENT}

The writer would like to thank to supervisors of Biology Education Program of Sebelas Maret University who has participated in research process and article writing, to principal, peers, and students who have worked well during collecting data in the field.

\section{REFERENCES}

[1] A. A. Eshetu, "Parental Socio-economic Status as a Determinant Factor on Academic Performance of Students in Regional Examination: Case of Dessie town; Ethiopia”. International Journal of Academic Research in Education and Review, vol. 3(9), pp. 247-256, 2015.

[2] A. Abdi, "The Effect of Inquiry-based Learning Method on Students' Academic Achievement in Science Course". Universal Journal of Educational Research, vol. 2(1), pp. 37 41,2014

[3] A. E. Monica, and O. Olatobosun, "Effects Of Scaffolding Strategy On Learners' Academic Achievement In Integrated Science At The Junior Secondary School Level”. European Scientific Journal, vol. 9(19), pp. 149-155, 2013.

[4] A. M. L Cavallo, M. Rozman, J. Blickenstaff, and N. Walker, "Learning, reasoning, motivation, and epistemological beliefs". Journal of College Science Teaching, vol. 33, pp. 18-23, 2003.

[5] A. Nasreen, and A. Naz, "A Study of Factors Effecting Academic Achievement of Prospective Teachers". Journal of Social Science for Policy Implications. Vol. 1(1), pp. 23-31, 2013.

[6] A. Rustaman, "Pengembangan Kompetensi (Pengetahuan, keterampilan, Sikap, dan Nilai) Melalui Kegiatan Praktikum Biologi”. Penelitian Jurusan Pendidikan Biologi FPMIPA UPI Bandung", 2005.

[7] A. T. Ejifor, A. O. Ajake, D. O. Oba, and D. E. Okpara, "Assessment of Influence of Education on Tourism
Development in Enugu State, Nigeria". American Journal of Tourism Research, vol. 1, pp. 33-42, 2012.

[8] C. Sumalee, and D. Kwanjai, "The Constructivist Learning Environments Model Enhancing Cognitive Flexibility For Higher Education: Validation Phase". Procedia - Social and Behavioral Sciences. vol. 46, pp. 3764 - 3770, 2005.

[9] Carin and Evan, "Teaching science trough discovery", Colombus: Merril Publissing Company, 1997.

[10] D. R. Cruickshank, D. B. Jenkins, and K. K. Metcalf, "The Act of Teaching". Fifth Edition. Boston: McGraw Hill Companies, 2009.

[11] F. Jieqiong, and Z. Li-fang, "The Role of Learning Environments in Thinking Styles". Educational Psychology, vol. 34(2). pp. 252-268, 2014.

[12] J. A. Castronova, "Discovery Learning for the 21st Century: What is it and how does it compare to traditional learning in effectiveness in the 21st Century". Valdosta.edu, vol. 1(1), pp. 1-12, 2002.

[13] J. Anghileri, "Scaffolding Practices That Enhance Mathematics Learning". Journal of Mathematics Teacher Education, vol. 9, pp. 33-52, 2006.

[14] J. Trna, E. Trnova, and J. Sibor, "Implementation Of InquiryBased Science Education In Science Teacher Training". Journal Of Educational And Instructional Studies In The World, vol. 2(4), pp. 199-209, 2012.

[15] Janneke van de Pol, V. Monique, O. Frans, and B. Jos, "The effects of scaffolding in the classroom: support contingency and student independent working time in relation to student achievement, task effort and appreciation of support". Instructional Science, vol.45, pp. 615-641, 2015.

[16] K. H. A. Nowak, R. Nehring, Tiemann, and A. Upmeier zu Belzen., "Assesing Students Abilities in Processes of Scientific Inquiry in Biology Using a Paper-and-Pencil Test". Journal of Biological Education, vol. 47(2), pp. 182-188, 2013.

[17] K. O. Oladele, A. O. Kazeem, and O. O. Akintayo, "Parental and Related Factors Affecting Students' Academic Achievement in Oyo State, Nigeria". International Journal of Social, Behavioral, Educational, Economic, Business and Industrial Engineering, vol. 8(9), pp. 3129-313, 2014.

[18] K. Veermans, "Intelligent Support For Discovery Learning. Netherlands". Twente University Press, 2003.

[19] Kemendikbud, "Peraturan Menteri Pendidikan dan Kebudayaan RI No.65 Tentang Standar Proses”. Jakarta: Kemendikbud, 2013.

[20] Kemendikbud, "Peraturan Menteri Pendidikan dan Kebudayaan RI No.22 Tentang Standar Proses". Jakarta: Kemendikbud, 2016.

[21] M. Suendarti, "The Effect of Learning Discovery Model on the Learning Outcomes of Natural Science of Junior High School Students Indonesia". International Journal Of Environmental \& Science Education, vol. 12(10), pp. 2132216, 2017

[22] N. Harianik, P. E. Suswandi, dan H. C. Diartho, "Dampak Objek Wisata Pulau Merah Terhadap Kondisi Sosial Ekonomi Masyarakat Desa Sumberagung Kecamatan Pesanggaran Kabupaten Banyuwangi". Artikel Ilmiah Mahasiswa 2016 Universitas Jember, 2016.

[23] N. L. Chotimah, A. M. Hety, dan W. Joko, "Pengaruh Status Sosial Ekonomi Orang Tua terhadap Prestasi Belajar Siswa". Jurnal Pendidikan Ekonomi, vol. 11(1), pp. 75-80, 2017.

[24] R. E. Slavin, "Cooperative Learning Teori, Riset dan Praktik". Bandung: Nusa Media, 2011.

[25] R. M. A. Khan, I. Nadeem, and T. Saina, "The influence of Parents Educational level on Secondary School Students Academic achievements in District Rajanpur". Journal of Education and Practice, vol. 6(6), pp. 76-79, 2016.

[26] R. Melani, Harlita, dan B. Sugiharto, "Pengaruh Metode Guided Discovery Learning Terhadap Sikap Ilmiah dan Hasil Belajar Kognitif Biologi Siswa SMA Negeri 7 Surakarta Tahun Pelajaran 2011/2012". Jurnal Pendidikan Biologi UNS, vol. 4(1), pp. 97-105, 2012. 
[27] R. Rahman, dan S. Maarif, "Pengaruh Penggunaan Metode Discovery Terhadap Kemampuan Analogi Matematis Siswa Smk Al-Ikhsan Pamarican Kabupaten Ciamis Jawa Barat”. Infinity jurnal ilmiah program studi matematika STKIP siliwangi Bandung, vol. 3(1), pp. 33-58, 2014.

[28] S. H. Jew, "Who Are Self-Discovery Learners Online? A Literature Review". USA: Constructing Self-Discovery Learning Spaces Online, 2012.

[29] S. Hotmika, S. Bornok, and Mukhtar, "The Effect of Discovery Learning Model to Students' Mathematical Concept Mastery". IOSR Journal of Research \& Method in Education (IOSR-JRME), vol. 7(5), pp. 18-23, 2017.

[30] Slameto, "Belajar dan Faktor-Faktor yang Mempengaruhinya". Jakarta: Rineka Cipta, 2005.

[31] Sugiyono, "Statistika untuk Penelitian". Bandung: Alfabeta, 2005.

[32] T. K. Ngang, N. Subadrah, and P. Bouphan, "Developing Instruments to Measuring Thinking Skills and Problem Solving Skills Among Malaysian Primary School Pupils". Procedia Sosial And Behavioral Science, vol. 116, pp. 37603764, 2013.

[33] T. Martaida, N. Bukit, and E. M. Ginting, "The Effect of Discovery Learning Model on Student's Critical Thinking and Cognitive Ability in Junior High School". IOSR Journal of Research \& Method in Education (IOSR-JRME), vol. 7(6), pp. 1-8, 2017.

[34] V. P. Coletta, and J. A. Phillips, "Interpreting FCI Scores: Normalized gain, Preinstruction Scores, and Scientific Reasoning Ability". American Journal of Physics, Vol 73(12), 2005.

[35] V. S. Andrini, "The Effectiveness of Inquiry Learning Method to Enhance Students' Learning Outcome: A Theoritical and Empirical Review". Journal of Education and Practice, vol. 7(3), pp. 38-42,2016.

[36] Y. Herdiana, Wahyudi, dan R. Sispiyati, "Effectiveness of discovery learning model on mathematical problem solving". The 4th International Conference on Research, Implementation, and Education of Mathematics and Science (4th ICRIEMS), vol. 4(4), pp. 1-8, 2017. 